\title{
RESTORE, REFORM OR TRANSFORM FORESTRY EDUCATION IN UGANDA?
}

\author{
Mukadasi Buyinza \\ Department of Community Forestry \& Extension, Makerere University, Uganda. \\ Pål Vedeld Noragric, Department of International Environment and Development Studies, \\ Norwegian University of Life Sciences, Norway.Email: pallve@umb.no
}

\begin{abstract}
The role of participatory approaches to forestry has increased dramatically, and meeting 112 the needs of people is now seen as a primary function of forestry. These changes present both strategic and practical challenges, constraints and opportunities for forestry education. The important changes in forestry education include the shift from teacher-to student-centred learning and rapid technological developments. If forestry education is to meet its new challenges, it needs to undergo deep transformation. This paper discusses the changing social perceptions and demands onto the forest sector and their implications to forestry education. It reflect on the current status of forestry education, and describes the drivers for change in the delivery of forest education in Uganda.
\end{abstract}

Keywords: Attitude goal, forestry education, forest sector, curricula, Uganda

\section{Introduction}

Forestry education, like the forestry sector itself, has evolved in response to changing markets, social attitudes and political goals and instruments. While research and education have contributed to their evolution, they have played a smaller role in the more recent economic, economic and social changes. There is a risk that forestry as a profession may become marginalized. Key decisions regarding forest policy practices will increasingly be made by individuals or organizations who lack adequate understanding of ecological diversity and ecosystem functions, fundamental issues in sustainable forest management and conservation, and the important social, economic, technical and cultural dimensions of forestry (Buyinza, 2004).

Just as changes are perceived in forestry practice, innovations are also emerging within education which have direct relevance to the development of forestry education. Likewise, within the broad sector of natural resources-related education and training, many have arisen due, particularly, to an intense debate about the need for improvement in the forestry education. In order to address the need for fundamental change in forestry education, it is important to focus not only upon issues relating to forestry practice, but also upon a range of educational issues which have a critical effect on the quality and effectiveness of forestry education. This reflects a paradigm shift in education and training from approaches rooted in content-led didactism towards pedagogical approaches based upon learning and participation, and related to the real needs of learners and of society. This major change in the way that forestry is increasingly being practiced has not yet influenced the university curricula. 
According to Podlubny (2002),

"Gone are the days of training programs that present technologists/technicians for a wide spectrum of technical jobs performed by rangers, conservation officers and industry forest technologists. These jobs were highly field-oriented and that the people working within the forests at a very practical level. The programs of today still provide the academic and field lab background to do the job of a technologist but the trend is towards a higher technology component and a greater emphasis on forest ecology and forest landscape".

Present day education of forestry technicians and technologists is not only in the form of field work, mapping, scaling and data collection, but also in communication, collaborative management, GIS, computers, adaptive management, stand establishment, silviculture, supervision and landscape management (Podlubny 2002).

In a new focus on forestry education, forest practitioners and forest workers will have to re-define their role and modify their educational training to reflect changing needs. Challenging working environments compatible with a new generation of high-tech forest practitioners need to be established by employers. Information technology will revolutionalize the delivery of forestry resources education and procedures and motivation for life-long learning.

In the face of such responsibilities, forestry education should also equip its graduates with a strong sense of ethics towards the forest, the broader environment and society. This ethical training must equip future foresters to play a more active role in the evolution of forestry and prepare them for change. It must also equip them to resist suggested changes that are in conflict with the broader management objectives and societal values (Baron and Byrne, 1999). They must understand and be able to effectively communicate the social, cultural, economic and ecological constraints that render public demands for certain changes impractical or contrary to the very values society wishes to sustain.

This paper has started with a presentation of the reciprocal relationships between society and its education system. This is followed by a description of the factors inducing change in society and highlighting the associated emerging trends in education. With the changing role of the forest sector, globalization and forestry policy shifts, educational institutions have to equip their graduates with a variety of non-traditional skills. There is therefore a need to reform the curricula and delivery of forest education. We use our personal experiences for more general reflection on the challenges of forestry education at Makerere University. By way of conclusion, we propose some recommendations for the future directions of forestry education in Uganda.

\section{Drivers of change in society}

The nature of forestry is changing rapidly, with social components becoming as important as the traditional biophysical components. The role of participatory approaches to forestry has increased dramatically, and meeting the needs of people is now seen as a primary function of forestry (Innes and Hoen, 2005). Increasingly, such needs are being defined through bottom-up approaches, by governments or present foresters and forest scientists are poorly equipped to deal with such change, that necessitates much broader nets of knowledge than has previously been required. At the undergraduate level, forestry programs are failing to teach the skills necessary for successful participation in 
this new form of forestry. Scientists who are genuinely interdisciplinary may have difficulties finding employment, and current academic reward systems do not cope well with individual contributions to team efforts. The problem extends to the forestry profession, with many professional foresters being ill-equipped for their new roles, while at the same time they and/or their employers remain reluctant to enter into any form of re-training.

Modern forestry in developed countries is increasingly becoming less production or mono-purpose oriented and more multipurpose oriented. The production sphere itself has been infiltrated by demands for delivery of public goods such as carbon sequestration, biodiversity conservation, environmental certification, outdoor recreation and multipurpose uses of various types, as a further consequence the number and type of actors and institutions involved in forest management is rapidly changing (Vedeld and 114 Krogh, 2005). The key factors that cause changes within the forest sector have been summarised under economic, social, political and environmental factors (Table 1).

Table 1. Drivers for change within the forest sector

\begin{tabular}{|l|l|}
\hline Factor & Description \\
\hline \multirow{5}{*}{ 1. Economic } & $\begin{array}{l}\text { Multipurpose oriented production; diverse needs and demands; multipur- } \\
\text { pose use of forest products and services }\end{array}$ \\
\cline { 2 - 3 } & Income generating and investment attracting role \\
\cline { 2 - 3 } & $\begin{array}{l}\text { Market-based instruments are increasingly common; and } \\
\text { Private sector institutions are more influential in forest policy }\end{array}$ \\
\cline { 2 - 3 } & Global competition \\
\cline { 2 - 3 } 2. Social & Revised property rights and tenure agreements \\
\cline { 2 - 3 } & Industrial needs \\
\cline { 2 - 3 } & Favourable consumer tastes and preferences \\
\cline { 2 - 3 } & Declining Central government role and public funding \\
\cline { 2 - 3 } & Increase in development role - supporting rural development \\
\hline & Population growth and livelihood sources \\
\cline { 2 - 3 } & Access rights and resources such as labour to exploit forests \\
\cline { 2 - 3 } & Participatory management processes \\
\cline { 2 - 3 } & Private sector involvement in forest sector \\
\cline { 2 - 3 } & Scientific discovery, education and technology change \\
\cline { 2 - 3 } & Property ownership and access rights \\
\hline
\end{tabular}




\begin{tabular}{|c|c|}
\hline \multirow{5}{*}{ 3. Political } & $\begin{array}{l}\text { Collaborative management approaches as opposed to "fortress forestry" } \\
\text { mentality; Forestland ownership transferred to private individuals, corpo- } \\
\text { rations and some communities }\end{array}$ \\
\hline & $\begin{array}{l}\text { Partnership model of contracting of the nature; contractual "concession" } \\
\text { forest management to private sector }\end{array}$ \\
\hline & $\begin{array}{l}\text { Laws and bylaws (spec. ban on certain species); Regulations, rights to } \\
\text { resource use; standards, non-tradable quotas etc. }\end{array}$ \\
\hline & $\begin{array}{l}\text { Decentralized and privatization; state-owned forest enterprises has been } \\
\text { transferred to the private sector }\end{array}$ \\
\hline & External partners \\
\hline \multirow{6}{*}{$\begin{array}{l}\text { 4. Environ- } \\
\text { mental }\end{array}$} & $\begin{array}{l}\text { Demand for public goods: carbon sequestration, biodiversity conserva- } \\
\text { tion, environmental certification, outdoor recreation, watershed manage- } \\
\text { ment }\end{array}$ \\
\hline & $\begin{array}{l}\text { Global commons and services e.g carbon sequestration, ozone Climate } \\
\text { change, depletion, protection of marine systems }\end{array}$ \\
\hline & $\begin{array}{l}\text { Environmental incomes and costs, taxes (on charcoal production); Subsi- } \\
\text { dies (on tree planting), tradable carbon quotas }\end{array}$ \\
\hline & $\begin{array}{l}\text { Pressures from both international and local actors with emphasis on how } \\
\text { environmental and social roles can be developed and paid for. }\end{array}$ \\
\hline & Green labelling of timber and certification, tradable quota permits \\
\hline & $\begin{array}{l}\text { Integration of environmental impact assessment plans in development } \\
\text { projects }\end{array}$ \\
\hline
\end{tabular}

Competition for use of and control over natural resources is increasing as a result of pressures from growing populations and the diverse interests of user groups. In the context of current trends of democratization, decentralization and devolution of authority, communities now have both a greater need and more opportunities to participate in natural resource management.

Vedeld and Krogh (2005), provides an integrative perspective of the complexity and uncertainty of human and natural systems, which asserts that human behavior and nature's dynamics are linked in an evolving systems; the seeming paradox of change and stability inherent in evolving systems is the essence of sustainable futures; the multipurpose re-orientation in forestry as an example of natural resource management displays the need for development of management proficiency not only related to multipurpose management, but also to handle social issues and interactions between conflicting actors. At the national level, changes are also evident. There is pressure to devolve forest management to rural communities and local government units. Forestry departments in many countries are shrinking as a result of tight public finances or the transfer of forestry-related functions to other (often environmentally-oriented) Ministries and yet they grapple with new, multiple roles, which sometimes contradict or compromise each other (Innes and Hoen 2005).

There has been transition of former centrally-planned economies to market-based economies; in structural adjustment programmes promoted by international lending institutions, which led many national governments to reduce public sector expenditures and 
price distortions; and the increasing globalisation of the world's economy, with trade and capital liberalisation and currency reform.

\section{Changes in society and education}

Forestry education will, both by necessity and design, continue to adapt to the changing technologies and practices relevant to forestry and education (Schamhart and Van, 1994). The essential questions for all of us engaged in forestry education include, how to: address the greater diversity in forests, forestry and education; handle the interdependencies between societal demands, forestry education and the domain of forestry; develop problem-based and student-centred learning in the face of resource and administrative constraints; strengthen the extent, relevance and accessibility of graduate-level forestry education; establish strong, dynamic and innovative forestry programmes amidst institutional re-organisations; development of more contemporary and better balanced curricula, reflecting both the natural and social science dimensions of forestry.

Klein (1996) argues that the key elements of reform for forestry education will, therefore, involve a shift from a discipline-based to an issue-based approach; more integrated and better balanced curriculum (technical, social and ecological); field-based learning and feedback (including research); in-service education linked to formal and informal education, and networking and linkages to address the emerging trends within the forestry sector.

Vedeld and Krogh (2000) argue that the major theoretical goal of any education system should be to develop a combination of theoretical knowledge and experience-based approaches that contributes toward better management of "nature-society" relationships. According to them, the proficiency goal is that such knowledge should enable institutions and candidates to interpret and be able to generate practical processes of social change in terms of empowerment, equitability and sustainability. The programme also includes an attitude goal where candidates should develop their ability to think critically and analytically and communicate effectively.

Graduates will need to become flexible, adaptable, and orderly managers of change, thinking strategy, thinking leadership, and thinking vision (Nordin 1999). They will need to be proficient in the communicative processes including interpersonal skills with people and society, experienced in procedures of integration, synthesis, design, and implementation, be Information Technology literate, and be committed to continuous learning, acquiring new talents and interests throughout life.

The educational environment will transform increasingly from didactic to interactive problem-based learning and professors will emerge as creative facilitators of knowledge, and have a profound influence on the development of forest education. The forestry schools will need creative partnerships at home and abroad to support their mandates in education, research, and public service (Nordin and Comeau, 2003). The forestry profession has been relatively unprepared for these events. Foresters have often been asked to deal with non-technical, socio-economic and political issues and they are at present not equipped with the means to do so, because of the way they are educated.

According to Vedeld and Krogh (2000), such assumptions should include the multipurpose nature of forests, involving social, economic and ecological services; forests will 
only persist as a consequence of international collective action; forestry institutions are increasingly challenged by changing demands, lack of funding and lack of perceived relevance to society; there is now a prevailing shift in educational philosophy from teacher-centred to a learner-centred focus; there should be a shift in emphasis from education of foresters towards education for the domain of forestry; and forestry education at all levels should foster repeated careful examination of its contexts, values and informed action.

Nationally, as well as internationally, there is a declining financial support for forestry in favour of broader environment and development programmes. Overall, forestry institutions, including forestry education, face difficulties in mobilizing national and international resources. In Uganda, the public sector is shrinking, affecting for example forestry extension, once a key employer of fresh graduates. The unemployment or under-employment of forestry graduates is high (Kamugisha, 1993).

In a new focus on forestry education, forest practitioners and forest workers will have to re-define their role and modify their educational training to reflect changing needs. Challenging working environments compatible with a new generation of high-technology forest practitioners need to be established by employers (Sayer and Byron, 1996). Information technology will revolutionalize the delivery of forestry resources education and procedures and motivation for life-long learning. The educational environment will transform increasingly from didactic to interactive problem-based learning and professors will emerge as creative facilitators of knowledge, and have a profound influence on the development of forest education. The forestry schools will need creative partnerships at home and abroad to support their mandates in education, research, and public service (Nordin and Comeau, 2003).

In the face of such responsibilities, forestry education should also equip its graduates with a strong sense of ethics towards the forest, the broader environment and society. This ethical training must equip future foresters to play a more active role in the evolution of forestry and prepare them for change. It must also equip them to resist suggested changes that are in conflict with the broader management objectives and societal values (Baron and Byrne, 1999). They must understand and be able to effectively communicate the social, cultural, economic and ecological constraints that render public demands for certain changes impractical or contrary to the very values society wishes to sustain.

Challenges of forestry education at Makerere University, Uganda

The shift to student-centred learning at the undergraduate level is challenged by, in particular, the economic circumstances of students, which requires them to engage in substantial part-time employment whilst they are studying, and limits the time and energy they are able to commit to their learning. Some welcome relief is afforded for a small number of students by scholarships and awards offered by forestry sector agencies and businesses, and by universities, but these are generally insufficient in number and magnitude to assist more than a small proportion of students.

There is limited capacity for Makerere University to expand traditional graduate programmes because of the substantial direct and opportunity costs to students associated with most graduate degrees. Furthermore, the government scholarship system intended to support students is so inadequate that even those with outstanding undergraduate qualifications and university awards are not able to secure scholarship support. Some 
employers and external partners are very supportive of graduate students, but in any case traditional on-campus graduate degree programmes are of limited relevance to many in the workforce and community.

The shift to student-centred learning at the undergraduate level is challenged by the economic circumstances of students, which requires them to engage in substantial part-time employment while they are studying, and limits the time and energy they are able to commit to learning. A small number of students receive scholarships and awards offered by forestry sector agencies and businesses, and by universities, but these are insufficient in number and magnitude to assist more than a small proportion of students.

\section{Enrolment and graduation}

118 The information presented in Table 2 shows the trend of graduation over years. The data provided clearly demonstrates the uncertainty under which the professional programmes are managed. It is clear that Faculty of forestry and Nature Conservation, Makerere University in Uganda suffers from major annual variations in student enrolment. This has a devastating impact on planning and implementing programmes. Considering that the capital investments (staff, classrooms, laboratories, equipment, and field training facilities) have already been made, there is a case here of poor utilization of capacity and facilities as well. Special attention is given to gender analysis.

Table 2. Number of forestry graduates from Makerere University in the last $\mathbf{1 0}$ years

\begin{tabular}{|c|c|c|c|c|c|c|c|}
\hline Acad. Year & Bachelors & & Masters & & PhD. & & Total \\
\hline & Male & Female & Male & Female & Male & Female & \\
\hline 1996 & 15 & 6 & - & - & - & - & 21 \\
\hline 1997 & 18 & 10 & - & & - & - & 28 \\
\hline 1998 & 20 & 8 & 1 & 1 & - & - & 30 \\
\hline 1999 & 20 & 14 & 2 & - & - & - & 36 \\
\hline 2000 & 21 & 17 & 3 & 1 & - & - & 42 \\
\hline 2001 & 18 & 10 & 2 & 2 & 1 & - & 33 \\
\hline 2002 & 30 & 16 & 1 & - & - & - & 47 \\
\hline 2003 & 46 & 25 & 2 & 2 & 1 & - & 76 \\
\hline 2004 & 42 & 20 & 4 & 2 & - & - & 68 \\
\hline 2005 & 48 & 25 & 2 & 1 & - & 1 & 77 \\
\hline Total & 278 & 151 & 17 & 9 & 2 & 1 & 458 \\
\hline
\end{tabular}

Our analysis does not present the trends in forestry training at certificate and diploma levels. This is because graduation at forestry certificate level dropped drastically after 1995, mainly due to low enrolment and to the consequent closure of the certificate programmes. The impact is seen directly in the quality and amount of technical services 
provided to forests, especially plantations. According to Kamugisha (1993), many forest plantations are very poorly maintained, especially regarding survival, pruning, thinning and quality management of harvesting technologies and processes.

\section{Funding of tertiary education}

The basic training facilities such as library and teaching materials, laboratories, and transport to fieldwork sites are lacking. National funding is intermittent, declining and largely from national resources. Donor funds are unpredictable, often depending on political environments and trends among other factors. It is fair to observe that despite the abundance of research money in research funding organizations, few staff seem to be adequately engaged with research funding organizations and reaping the benefits of graduate research (Temu et al., 2003).

There are significant resource and administrative constraints to developing field-and problem-based learning. These constraints reflect both the relatively high staff and resourcing costs of supporting both these forms of learning, and the practical difficulties of integrating a curriculum structured to facilitate field- and problem-based learning with curricula that do not have such a focus. This problem can be particularly acute in the case of interdisciplinary programmes which depend on scheduling the input of a number of disciplines.

\section{Adequacy of training}

Practical work is essential in training professional foresters, and a minimum period of practical work is usually specified as a requisite before a degree will be awarded. However, the requirements for a manager of a natural resource are many, and the training given is therefore usually extremely broad, concentrating in the first two years at most universities on the basic subjects, in particular on the biological sciences. However, it has become increasingly evident that it is impossible to cover adequately the essential forestry aspects in one year, especially the working plan (Temu et. al., 2003).

\section{Conclusions}

The current forestry education objectives, content and delivery methods in Uganda do not adequately respond to the changing needs of conservation, management and sustainable development nor cover adequately issues of food security and poverty alleviation. Expectations from foresters have expanded to deal with an ever increasing range of stakeholders. Forests are intimately involved in issues of food security and poverty alleviation. Governments should give adequate emphasis to these issues in education programmes. Without undermining the importance of traditional forestry-related subjects, forestry students recognize that forestry education should be better informed about the needs of the entire forest sector, instead of the narrow view presented by the current system. Besides the good knowledge base of basic forest sciences, broader skills in communication, language and technical knowledge should be emphasised.

\section{Acknowledgements}

This study was conducted with funding from Makerere University Capacity Building Programme under the Innovations at Makerere Programme (I@Mak. Com). The authors 
are grateful for the institutional support received from Faculty of Forestry, Makerere University and Noragric, Department of International Environment and Development Studies, Norwegian University of Life Sciences.

\section{References}

Baron, R.A. and Byrne, D. 1999. Social Psychology. Eighth Edition. Prentice-Hall of India Private Ltd, New Delhi. Pp 142-152.

Boden, M. 1996. What is Interdisciplinarity? In: R. Cunningham (ed.). Euroscientia Conference. Interdisciplinarity and the Organisation of Knowledge in Europe. EU.

Buyinza, 2003. Forest Work in Villages. A guide for field workers and facilitators. I@Mak. com Curriculum Review, Department of Community Forestry and Extension, 120 Makerere University, Fountain Publishers Kampala, Uganda.

Buyinza, M. 2004. Forestry Education in a changing landscape: emerging lessons from Uganda. Makerere Journal of Higher Education 1: 62 - 70.

Comeau, R. 1997. Continuing Forestry Education Programs in Canada. Forestry Chronicles. 73: 286-289.

Egneus, H., K. Bruckmeier, M. Polk. 2000. The Nature of Interdisciplinarity. Report to the Interfaculty Committee for Thematic Studies. Gotenborg University.

Innes, J.L. and Hoen, H.F. 2005. The importance for forestry of changes in the socio-economic environment. CABI Publishing, Wallingford

Innes, J.L. 2005. Multidisciplinarity, Interdisciplinarity and training in forestry and forestry research. Forestry Chronicle 81 (3), 324-329.

Kamugisha J.R. 1993. Management of Natural Resources and Environment in Uganda: Policy and Legislation Land Marks, 1890-1990 Report No. 11.

Klein, J. T. 1996. Crossing Boundaries. Knowledge, Disciplinarities and Interdisciplinarities. University Press of Virginia, Charlottesville and London.

Lattuca, L.R. 2001. Creating Interdisciplinarity: Interdisciplinary research and teaching amonmg college and university faculty. Vanderbilt University Press, Nashville, TN. pp.296.

Nordin, V.J. 1999. Think strategy. Think leadership. Think vision. Forestry Chronicle. 75: $357-360$.

Nordin, V., and R. Comeau R., 2003. Forest Resources education in Canada. The Forestry Chronicle 73: 7999 - 808.

Podlubny, D. 2002. Canadian Tech Diploma Courses over the Years. Forest Chronicles. 78: 248-249.

Sayer, J.A. and Byron, N. 1996. Responding to change. New visions for forestry institutions. Conference proceedings of the Oxford Summer Course Programme 1996. Oxford Forestry Institute.

Schamhart, and W. Van den Bor. 1994. Curriculum Development in Higher Agricultural Education. A Case from Benin in Higher Education Policy, 1994.

Temu, A., L. Mwanje, and Mogotsi, K. 2003. Improving agriculture and natural resources education in Africa: a stitch in time. World Agroforestry Centre, Nairobi.

Vedeld, P. and E. Krogh. 2005. Crafting Interdisciplinary in an MSc. Programme in Management of Natural Resources and Sustainable Agriculture. The Forestry Chronicle. Vol. 81. No. 3. 